BARBARA BIBIK

Uniwersytet Mikołaja Kopernika

\title{
Zapomniani tłumacze starożytnych greckich tragedii
}

Korpus polskich przekładów greckich tragedii, na podstawie wzmianek we wstępach do przekładów czy w recenzjach przekładów sięgających początków xIX wieku, liczy około stu pozycji - są to tłumaczenia fragmentów, pojedynczych utworów bądź całej zachowanej spuścizny danego tragika. $Z$ tego korpusu powszechnie funkcjonują (w świadomości literackiej bądź teatralnej) przekłady: Zygmunta Węclewskiego, Kazimierza Morawskiego, Jana Kasprowicza, Mieczysława Brożka, Stefana Srebrnego, Jana Łanowskiego czy, ostatnio, Antoniego Libery. Być może do tego grona, dla nieco bardziej wtajemniczonych, można by dodać Kazimierza Kaszewskiego, Józefa Szujskiego, Jana Czubka, Ludwika Hieronima Morstina, Artura Sandauera czy, ostatnio, Roberta R. Chodkowskiego. Dla teatrologów zaskoczeniem nie są nazwiska Juliusza Osterwy, Helmuta Kajzara, Stanisława Hebanowskiego czy Mirosława Kocura. Jak łatwo zauważyć, są to nazwiska filologów i/lub tłumaczy czy reżyserów aktywnych dopiero od drugiej połowy (wręcz końca) xIx wieku do chwili obecnej. Pozostali dziewiętnasto- i dwudziestowieczni tłumacze (skądinąd mniej bądź bardziej znani), jak Jan Mihanowicz, Alfons Walicki, Antoni Małecki, Franciszek Wężyk, Józef Biernacki, Tadeusz Eliaszewicz, Wincenty Smaczniński, Lucjan Siemieński, Fryderyk H. Lewestam, Hugon Wróblewski, Stanisław Grabowski, Antoni Mierzyński, Ludwik Eminowicz, Bogusław Butrymowicz, Stanisław Karpiński, 
Stanisław Dygat czy Nikos Chadzinikolau, śmiem twierdzić, są zapomniani bądź w ogóle nieznani. W trakcie przygotowań do poznańskiej konferencji poświęconej czynnikowi ludzkiemu w przekładzie najbardziej zatem zainteresowało mnie przyjrzenie się temu, co działo się w pierwszej połowie xıx wieku, oraz tym tłumaczom, którzy poprzedzili owe wielkie nazwiska Węclewskiego czy Morawskiego, a także próba uchwycenia początków przekładu greckich tragedii na język polski na szerszą skalę, które zapewne sięgają tego właśnie okresu (zapewne, ponieważ nie mam pewności, czy wciąż nie leżą gdzieś w ukryciu jakieś przekłady). Przed tym okresem, jak wiadomo, pierwsze próby podjęte zostały już w XVI wieku. Pierwsza przez Jana Kochanowskiego, który przetłumaczył fragment Alkestis Eurypidesa (o której to próbie badacze przedmiotu wyrażają się z dużą aprobatą); drugą natomiast był przekład Wincentego Jakubowskiego Antygony Sofoklesa na poemat epiczny (o tej z kolei próbie, wzmiankowanej w literaturze przedmiotu, Piotr Chmielowski w 1876 roku napisał, że: „utwór ten już za [Michała Hieronima - B.B.] Juszyńskiego ${ }^{1}$ do nadzwyczajnych liczący się rzadkości, dziś prawie do mitów należy" (Chmielowski 659)). Odtąd aż do początku XIX wieku literatura przedmiotu nie wspomina o żadnym przekładzie z greckiej literatury dramatycznej (ale czy rzeczywiście nie powstał wówczas żaden przekład bądź jakakolwiek próba przekładu choćby fragmentu?). Za przyczynę takiego stanu rzeczy (przynajmniej do czasu ożywienia znajomości języków starożytnych wynikłego ze sporów dotyczących edukacji prowadzonych między pijarami a jezuitami) podaje się niekiedy upadek wykształcenia oraz obniżającą się znajomość języków starożytnych do tego stopnia, że utwory te musiały być zapożyczane przez literaturę francuską.

Tymczasem w pierwszym numerze nowo powstającego „Tygodnika Wileńskiego" ukazującego się od roku 1816 Aleksander Żołkowski, wydawca, napisał we wstępie: „Nadto przekład Poezyi mianowicie z poetów starożytnych jest zawsze pożądany” (Żołkowski 2). To ładne zdanie zawierające explicite stwierdzenie, że pożądana jest twórczość przekładowa, że pożądana jest starożytność, że pożądana jest poezja starożytna, chciałabym, aby stało się punktem wyjścia dalszych rozważań. Przy czym na początku należy wyjaśnić od razu dwie kwestie, które wskażą na pewne uwikłanie przekładów tragedii czy w ogóle starożytności w tym okresie.

Pierwszą jest kwestia genologiczna. Ówcześni - jak wskazują poetyki i podręczniki rymotwórstwa z XVIII i początków XIX wieku, a co warto podkreślić - pod pojęciem poezji rozumieją nie tylko utwory liryczne, ale także utwory dramatyczne czy wręcz literaturę piękną w ogóle (Kraskowska, Kwiatkowska, 
Grądziel-Wójcik 81)². Taka klasyfikacja, szczególnie w odniesieniu do starożytnych utworów posługujących się różnymi miarami wersowymi i wykonywanych przy akompaniamencie muzyki, nie dziwi; każe się jednak zastanowić, kiedy (i dlaczego?) nastąpiło oddzielenie dramatu od poezji (przynajmniej w teorii literackiej) i czy przypadkiem takie podejście nie zaważyło na powszechnym przekonaniu (sformułowanym lata później przez Jana Parandowskiego, zob. Parandowski 302), że „wiersz należy tłumaczyć wierszem”, i w związku z tym na znacznej przewadze poetyckich nad prozatorskimi przekładów z tragików starożytnych (co swoją drogą jest ciekawe w zestawieniu z dominującym wpływem w owym czasie francuskiej kultury i francuskich przekładów, które z kolei w przeważającej mierze, mimo pojawiających się pewnych odrębnych tendencji (por. Garnier 33-64), są przekładami prozatorskimi, jeśli chodzi o tłumaczenia tragików greckich; nie będę jednak tej kwestii kontynuować).

Drugą natomiast jest kwestia „pożądania” twórczości antycznej. Dzisiaj to pożądanie w coraz mniejszym stopniu wydaje się oczywiste, niemniej wówczas starożytność wciąż stanowiła ważny, by nie powiedzieć podstawowy kanon kultury europejskiej - w owym czasie zaś bardzo ważny kanon estetyczny, a i ideologiczny, jako że jest to okres napięcia między oświeceniowymi zwolennikami klasycyzmu a zwolennikami przenikającego na polskie tereny romantyzmu (sporu, który z pełną mocą wybuchnie dwa lata później, w 1818 roku, wraz z publikacją rozprawy Kazimierza Brodzińskiego O klasyczności i romantyczności, tudzież o duchu poezji polskiej w „Pamiętniku Warszawskim”, i będzie się toczył przez kilka lat). Fakt ten, oczywiście, od razu rodzi pytania o uwikłanie starożytności, w tym przekładów, w ten estetyczny spór.

Mając to na uwadze, postawiłam sobie pytanie o to, jak popularna była twórczość przekładowa tragedii starożytnej w pierwszej połowie XIX wieku i jak przedstawiają się zapomniane początki przekładów tragików greckich.

W tym samym tomie „Tygodnika Wileńskiego”, w którym jest wypowiedź Żołkowskiego, w numerze 10 znajdujemy przekład Ludwika Sobolewskiego wersów 94-141 (parodos) z Trachinek Sofoklesa (Sobolewski 159). Trachinki nie wydają się najbardziej oczywistym wyborem spośród tragedii starożytnych (do dzisiaj nie miała miejsca ani jedna inscenizacja tego dramatu na polskiej scenie, jeśli wierzyć archiwum wirtualnemu e-teatr.pl; przekładana też była rzadko, jedynie przez Węclewskiego, Kaszewskiego i Chodkowskiego), niemniej nie bez powodu przyciągnęły uwagę Sobolewskiego. Wybór ten kieruje nas bowiem do jednej z najważniejszych postaci w tym czasie - człowieka, który zdaniem wielu ożywił zainteresowanie starożytnością i z pewnością przyczynił 
się do powstawania przekładów z literatury antycznej. Chodzi o Gotfryda Ernesta Groddecka (1762-1825), który w 1808 roku opublikował krytyczną edycję Trachinek (dwa lata wcześniej natomiast edycję Filokteta Sofoklesa). Groddeck był filologiem klasycznym, profesorem Cesarskiego Uniwersytetu Wileńskiego. To jemu przypisuje się rozbudzenie studiów klasycznych i wprowadzenie nauk humanistycznych „do naszej prowincji” (Węclewski 1876: 83). Wspierany przez księcia Adama Jerzego Czartoryskiego był twórcą powołanego w 1810 roku seminarium filologicznego. Wykładał na nim między innymi Homera, Sofoklesa czy Eurypidesa.

Wileńskie seminarium filologiczne powstało zresztą z inicjatywy księcia Czartoryskiego, który żywił nadzieję, że dzięki niemu nauka starożytności „zakorzeni się u nas” (Węclewski 1876: 84), a jego absolwenci będą, „obeznawszy się dokładnie z językami starożytnymi i ze starożytnością literaturę ojczystą [wzbogacać - B.B.] dobrymi przekładami autorów klasycznych" (Węclewski 1876: 80); szczególnie zaś miał namawiać Groddecka, by ten nakłaniał do przekładów Plutarcha. Niestety, w zestawieniach przekładów Plutarcha nie znalazłam informacji, by ze szkoły Groddecka „wyszedł” jakiś przekład; niemniej samo oczekiwanie, żeby tłumaczyć właśnie tego autora starożytnego chyba nie dziwi, biorąc pod uwagę jego moralizatorskie i dydaktyczne zacięcie. W każdym razie, „nigdzie i nigdy”, jak pisał Stanisław Cywiński,

nie ukazuje się tyle przekładów, przeważnie rozumnie i celowo dobranych, z obcych języków, co w tym czasie [I połowa XIX wieku - B.B.] w Wilnie. Więc z literatur klasycznych: Pindara tłumaczy Wiernikowski (1824) i J. Korsak (1826); Sofoklesa dwie tragedie (Trachinki i Edyp w Kolonie) - T. Eliaszewicz (1829), oraz Edypa króla - A. Walicki (1845); Eurypidesa - Oresta przekłada Eliaszewicz (1829 [sic! - B.B.]); Grzegorza z Nazjanzu x. Herburt (1843); Cycerona wydają w przekładzie E. Słowacki (1826) i Żukowski (1838 i 1840); Plutarcha tłumaczy Kraszewski (w rękopisie, 1828); Longina przekładają Korzeniowski (1819) i Kowalewski (1823); Owidiusza - Żebrowski (1821), E. Słowacki (1826) i Kowalewski (1823); Horacego tłumaczą: Jeżowski (1821), J. Korsak (1823), E. Słowacki (1826), A. Moszyński (1836), oraz x. A.S. Krasiński; Wergilego tłumaczą: Kotiużyński (1821), J. Korsak (1825) i E. Słowacki (1826); tenże Tacyta (1826); Lucjana - Szulc (1819); Lukrecjusza - L. Borowski (1820); Liwiusza - E. Słowacki (1826) i Ign. Jagiełło (1828) (Cywiński 17).

Do uczniów Groddecka z pewnością należeli: wspomniany wcześniej Ludwik Sobolewski (ukochany uczeń i przyjaciel), z wyżej wymienionych: Tadeusz 
Eliaszewicz, Jan Wiernikowski, Ignacy Jagiełł, Mamert Herburt, Józef Jeżowski, Dominik Szulc, Józef Szczepan Kowalewski. Oczywiście najczęściej wymienianym (i pamiętanym) uczniem Groddecka był Adam Mickiewicz.

W interesującym mnie okresie w 1824 roku Trachinki w całości przetłumaczyć miał także Eliaszewicz. Przekład ten jest kilkukrotnie wzmiankowany: w Wiadomościach Literackich w tomie 2 „Biblioteki Warszawskiej” (1864); przez Kaszewskiego w jego wstępie do Trachinek publikowanych w „Bibliotece Warszawskiej” (Kaszewski 6); przez Chmielowskiego w „Ateneum” (Chmielowski 660) w recenzji przekładów Węclewskiego; przez Romana Zawilińskiego w „Bibliotece Warszawskiej” (Zawiliński 370) w recenzji przekładów z Sofoklesa. O samym autorze niestety niewiele można powiedzieć; był (mało znanym) uczniem filologii Uniwersytetu Wileńskiego (tu zaś niewątpliwie uczniem Groddecka) (Sowiński 145). Jest również wymieniany jako jeden z autorów nowożytnych (obok Groddecka właśnie), z których dzieł miał korzystać Mickiewicz, przygotowując wykłady lozańskie (Piechota 146). Jego przekład dedykowany był Janowi Wiernikowskiemu³, Józefowi Kowalewskiemu, Feliksowi Kołakowskiemu „na pamiątkę najczystszej i nigdy niezłamanej przyjaźni” (wszyscy byli członkami stowarzyszenia filomatów bądź filaretów, wszyscy zostali zesłani za tę działalność). Mimo iż autor wzmianki w „Bibliotece Warszawskiej” (1864: 149) pisał, że rymowany przekład Eliaszewicza zasługuje na publikację i wkrótce zostanie ogłoszony w jednym z kolejnych numerów czasopisma, tekst pozostał w rękopisie i ostatecznie nigdy nie został opublikowany. Kaszewski natomiast pisał, że ów rymowany przekład to

szanowna praca: widać w niej należyte zrozumienie tekstu nie tylko literalne ale i duchowe i artystyczne, widać usiłowania do wydobycia z naszego języka zwrotów godnych odpowiadać wyrażeniom mistrza greckiego; ale z tem wszystkiem jest to łamanie pierwszych lodów. Eliaszewicz snadź nie był poetą, bo nie stworzył sam sobie języka jak jego kolega Mickiewicz [...] praca jego już dzisiejszym wymaganiom językowym pod estetycznym względem ani w toku ani w wersyfikacji nie odpowiada (Kaszewski 6-7).

3 1799-1877; językoznawca; student Uniwersytetu Wileńskiego; jeden ze skazanych w procesie Filaretów, zesłany w 1823 roku; w 1824 roku ukazał się w Wilnie jego przekład Pindara (prozą).

4 1801-1878, filolog klasyczny, orientalista; student Uniwersytetu Wileńskiego; członek stowarzyszenia Filomatów; tłumacz między innymi Metamorfoz Owidiusza; profesor Uniwersytetów w Kazaniu i w Wilnie. 
Podobnie wygląda sytuacja przekładu Prometeusza w okowach Ajschylosa autorstwa Józefa Gabriela Alojzego Biernackiego (1774-1834) herbu Poraj z roku 1815, który znajduje się w rękopisie (rkp 271) w bibliotece Towarzystwa Przyjaciół Nauk w Poznaniu (Aischylos 155). Autor tego przekładu był uczestnikiem insurekcji kościuszkowskiej, wojen napoleońskich i powstania listopadowego. Miał być starannie wykształcony (Staszewski 7); był zaufanym człowiekiem generała Jana Henryka Dąbrowskiego, a także członkiem loży masońskiej (Staszewski 21). Wybór Prometeusza w okowach jest nieco zaskakujący. Wprawdzie utwór ten należy do najwybitniejszych Ajschylosa (wzmiankowany jest w tak zwanej triadzie bizantyńskiej, czyli najmniejszym szkolnym wyborze trzech najlepszych sztuk danego autora przepisywanych od czasów bizantyjskich) i jest jednym z najpopularniejszych w XIX wieku, to jednak popularność zyskuje dopiero po 1830 roku (na przykład w kulturze brytyjskiej, gdzie pojawiają się przekłady Percy'ego Bysshe'a Shelleya czy Elizabeth Barrett Browning), a w kulturze polskiej wręcz w drugiej połowie XIx wieku (wprowadzenie Ajschylosa do szerszej świadomości Polaków jest niewątpliwą zasługą Węclewskiego). Czy Biernacki wybrał i przetłumaczył tragedię podczas rekonwalescencji po odniesionych w 1813 roku poważnych ranach w starciu pod Skarszewem (Staszewski 21)? Czy może powodowany innymi, trudnymi wydarzeniami, jak mogłaby na to wskazywać dedykacjas? Niestety, nie mamy żadnych informacji na ten temat, choć obie perspektywy wydają się kuszące. Przekład jest rymowany (o układzie rymów aabb lub abab, sporadycznie abba), w partiach dialogowych tłumacz posługuje się jedenastozgłoskowcem i niekiedy ośmiozgłoskowcem (z rzadka pięciozgłoskowcem), w partiach chóralnych i śpiewanych wersami o różnej liczbie sylab z przewagą dziesięcio- lub jedenastozgłoskowców i 8 zgłoskowców.

W rękopisach miały również pozostać przekłady Antygony i Medei Alfonsa Walickiego (1808-1858) (Estreicher 10; Nekrologi 375; Przewodnik 12; Zdanowicz 146), o którym warto wspomnieć, ponieważ należał do ostatnich uczniów Groddecka (Wołoszyński 122, 305). Był filologiem-hellenistą, znajomym Józefa Ignacego Kraszewskiego z czasów gimnazjalnych, profesorem Uniwersytetu w Charkowie. Uchodził za znawcę literatur starożytnych i wybitnego uczonego. Był pierwszym tłumaczem Fausta Goethego na język polski (część pierwsza wydana została w 1844 roku, część druga pozostała w rękopisie). Jedynym jego opublikowanym przekładem jest Król Edyp, który ukazał się w drugim tomie

5 Przekład opatrzony jest następującą dedykacją: „Naywspanialszego Tytana / Naystalszego między bogi / Naylepszej składam pod nogi”. Z dopiskiem: „Pannie Wyganowskiej / swej ulubionej, zmarłej w Smiłowie / panną" (Prometeusz w okowach, źródło elektroniczne). Za wyjaśnienie dziękuję Panu Wojciechowi Grasiowi z Działu Zbiorów Specjalnych Biblioteki Poznańskiego Towarzystwa Przyjaciół Nauk. 
Arcydzieł dramatycznych w przekładach Józefa Korzeniowskiego i Walickiego w Wilnie w 1845 roku (nie wiemy, kiedy tekst został przetłumaczony). Wybór Króla Edypa jest jednym z najoczywistszych. Tekst ten znajduje się w tak zwanej triadzie bizantyńskiej; jest jednym z najpopularniejszych tekstów Sofoklesa, szczególnie od czasów pochwały Arystotelesa wyrażonej w Poetyce (a trzeba pamiętać o jej wpływie na poetyki klasycystyczne), a i Sofokles cieszy się największą estymą niemal do końca xix wieku (Srebrny 367). Przekład jest nierymowany w partiach dialogowych (jedenastozgłoskowiec z drobnymi wyjątkami, czasem trzynastozgłoskowiec), natomiast w partiach chóralnych rymowany, z przeważającym układem odpowiadających sobie akcentów i rymów między strofą a antystrofą. Spotkał się z dość ostrą krytyką Węclewskiego:

Walicki w dyalogach ani miar ani rymu nie zachowuje, a chóry obydwóch [Kaszewskiego i Walickiego - B.B.] bez miar, bez harmonijnego związku strof $z$ antistrofami, o równej tylko liczbie sylab [niekiedy przecież Alf. Walicki w śpiewach chórowych usiłuje w strofach i antistrofach miarę oryginału naśladować - przyp. Z.W.] [...] język Walickiego zaciemny, jałowy i zaniedbany, [...] daleki od poety greckiego, choć trudno mu miejscami i powagi odmówić, ścisłego trzymania się tekstu i unikania zbytecznych ozdób (Węclewski 1861: 187).

A przecież Węclewski, wydając swoje przekłady z Ajschylosa i Sofoklesa, w jakiś sposób nawiąże do zaproponowanej przez Walickiego formy oddania miar wierszowych: rymować będzie partie chóralne, partie dialogowe natomiast zostawi nierymowane.

W tym miejscu dotykamy kwestii przekładu antycznych miar wierszowych na język polski; dyskusji, która niewątpliwie w odniesieniu do przekładu starożytnych tragedii już w tym momencie się rozpoczyna. Czy należy tłumaczyć wierszem rymowanym, ponieważ wiersz polski od swoich początków był rymowany, rym należał do najważniejszych ozdób wiersza i poezja rymowana była najpowszechniejsza, czy też można od tej zasady odstąpić. W Kursie Poezyi Korzeniowskiego wydanym w Warszawie w 1829 roku jego autor jakkolwiek przyznaje, że rym należy do ważnych ozdób wiersza i sprzyja jego harmonii, to przestrzega, by „poezji na rymotwórstwo nie zamieni[a]ć”; wskazuje też, że może warto by uwolnić się od rymu, aby w tragediach uczynić dialog naturalniejszym i łatwiejszym, przy czym zaznacza, że by to

nastąpić mogło, potrzeba, aby który pisarz, z prawdziwie poetycznym talentem, ośmielił się pójść przeciw powszechnemu prawie mniemaniu, 
i pięknościami myśli, obrazów i uczuć przeprosił nasze ucho za pozbawienie go przyjemności, jaką mu rym sprawuje (Korzeniowski 68).

Nie wszystkie przekłady w tym, jak i późniejszym czasie, w okresie dominacji poezji rymowanej, są jednak rymowane; gdzieś pod powierzchnią oficjalnej poezji rozwijają się formy sprzeczne z oczekiwanymi, które może stanowią swoisty dialog ze współczesnością, by zachować to, co właściwe dla poezji greckiej - rytm, a nie rym.

Z nazwiskiem wspomnianego wcześniej Eliaszewicza wiąże się jeszcze przekład Edypa w Kolonie, tym razem opublikowany w Wilnie w 1829 roku (do którego jednak nie udało mi się dotrzeć; fragment znajduje się we wzmiankowanej krytycznej recenzji Zawilińskiego). Sam Eliaszewicz brał udział w sporze między klasykami a romantykami, publikując w „Dzienniku Wileńskim” cykl uwag pod tytułem Ogólne uwagi nad klasycznością i romantycznością (Eliaszewicz 1828: 43-57, 73-87, 169-195) i opowiadając się za poezją klasyczną, tj. starożytną, w której zawiera się prawdziwa poezja, dobry smak i poprawność oraz z natchnienia której pochodzi wszystko, co Europa ma najlepszego z dzieł sztuk pięknych. Idea wielokrotnie powtarzana w tym czasie (by wymienić tylko z tego okresu Korzeniowskiego, Słowackiego, Groddecka, Eliaszewicza), szczególnie przez klasycystów (przy czym stosunek wymienionych do idei klasycystycznych nie zawsze był kategoryczny).

Powtarzana jest również informacja jakoby Eliaszewicz był autorem pierwszego pełnego przekładu tragedii Eurypidesa na język polski, mianowicie Orestesa, z 1829 roku. Niewątpliwie jest to pomyłka. Eliaszewicz jest tłumaczem wspomnianego wyżej Edypa w Kolonie Sofoklesa; poza przekładem jest również autorem opublikowanego na temat tego dramatu tekstu w „Dzienniku Wileńskim” w 1829 roku pod tytułem Wiek Sofoklesa, w którym pisał Tragedyą, Edyp w Kolonie. Orestesa natomiast przetłumaczył Jan Mihanowicz (1783-1814), wychowanek kolegium jezuickiego w Witebsku, jezuita, nauczyciel w gimnazjum w Witebsku a później również w kolegium w Połocku. Druk z 1829 roku w Wilnie jest zaś de facto przedrukiem z „Miesięcznika Połockiego”, w którym przekład Orestesa, po śmierci autora, był publikowany w częściach - w tomie drugim i trzecim - w roku 1818. Co ciekawe, Orestes również nie należy dzisiaj do najpopularniejszych tragedii Eurypidesa (w Polsce na scenach teatralnych był dotąd wystawiany dwukrotnie, po raz pierwszy w 2012 roku; tłumaczony natomiast, poza Mihanowiczem, jedynie w zbiorach wszystkich tragedii Eurypidesa przez Węclewskiego, Kasprowicza, Łanowskiego oraz Chodkowskiego). Trzeba jednak podkreślić, że Orestes znajdował się we wspominanej już tak zwanej triadzie bizantyjskiej; obok Fenicjanek i Hekabe był jednym z najpo- 
pularniejszych dramatów Eurypidesa oraz bardzo reprezentatywnym dla jego twórczości (Łanowski 182). Mihanowicz przełożył Orestesa językiem pięknym, zwięzłym i jasnym, posługując się wierszem rymowanym (Grzebień, źródło elektroniczne) (bardzo regularnym o układzie aabb), w partiach dialogowych jedenastozgłoskowcem, w partiach chóralnych wierszami o różnej liczbie sylab. To jednak, co wzbudza chyba największe zaskoczenie, to podział na akty i sceny. Oczywiście aktów jest pięć zgodnie z wytycznymi Sztuki poetyckiej Horacego (por. Skwara 62-65; O dramatyce 218; Tomkowicz 288), która stanowiła wzór dla poetyk klasycystycznych (por. Wężyk 1822: 97; Słowacki 1833: 285; Korzeniowski 208). Mihanowicz miał zostawić w rękopisach przekłady Fenicjanek Eurypidesa oraz Króla Edypa Sofoklesa. Niestety, nie jest znany ani los tych rękopisów, ani żadne dalsze szczegóły ich dotyczące.

Jeśli chodzi o omawiane początki, jednym z problemów jest także to, że mamy mało całościowych przekładów tragedii w tym czasie. Poza wzmiankowanym wyżej (i pewnym) Orestesem (i późniejszym jednak Królem Edypem) znajdujemy jeszcze przekład Króla Edypa, którego autorem jest Franciszek Wężyk (1785-1862), dramato- i powieściopisarz, poeta, tłumacz, krytyk literacki, członek Towarzystwa Przyjaciół Nauk. Pisze o nim, że stworzył go w 1804 roku, co stawiałoby ten przekład na pierwszej pozycji wśród polskich tłumaczeń tragików greckich, jeśli chodzi o całe utwory. I biorąc pod uwagę pozycję tak Sofoklesa, jak i Króla Edypa od czasów Arystotelesa, chyba nie powinno dziwić, że to ten utwór otwiera historię polskich przekładów. W jego powstanie W $1802^{6} / 1804$ roku powątpiewa jednak Chmielowski (Chmielowski 66o), gdyż, jak twierdzi, Wężyk musiałby go przetłumaczyć, mając 17 lat (co nie jest wszakże niemożliwe; od 1801 roku był studentem studiów prawniczych Uniwersytetu Jagiellońskiego). Wężyk pisze, iż przetłumaczony w 1804 roku tekst przejrzał w 1856 roku, na zakończenie swojego pisarskiego zawodu (Wężyk 1878: 339) (nie jesteśmy jednak w stanie tego potwierdzić). Opublikowany został natomiast pośmiertnie w 1878 roku w Krakowie nakładem rodziny autora. Wężyk jest również autorem rozprawy $O$ poezji dramatycznej zamówionej, a następnie odrzuconej przez Warszawskie Towarzystwo Nauk w roku 1811 (po wprowadzeniu zmian ukazała się ona w częściach jako dodatek do dramatów autora wydanych w roku 1821 i 1822; w całości dopiero w 1878 roku), szczególnie ze względu na to, jak się sądzi, że doceniał twórczość Szekspira a krytycznie wyrażał się o twórczości Racine’a, dopominał się pewnej modernizacji poezji dramatycznej, pewnego rozluźnienia w kwestii jedności miejsca i czasu oraz

6 Ten rok jako rzekomą datę powstania przekładu podaje Chmielowski za Estreicherem (Chmielowski 660). 
dopuszczenia nowych trendów (takich jak zwrot ku naturze, ku poznaniu serca ludzkiego czy zróżnicowanie postaci) (Czwórnóg-Jadczak 46).

Wężyka, chronologicznie, poprzedzają jedynie przekłady fragmentów greckich dzieł dramatycznych opublikowane w Allegoriach starożytnych (1801) przez Filipa Neriusza Golańskiego (1753-1824), teoretyka i krytyka literackiego, publicystę, tłumacza, wychowanka pijarów i pijara, profesora w Szkole Głównej Wielkiego Księstwa Litewskiego. Są to wyimki z Ifigenii w Taurydzie Eurypidesa oraz z Elektry i Filokteta Sofoklesa (pisarza „czułego, wspaniałego i zadziwiającego w swych sztukach, [który - B.B.] [...] nigdy się jeszcze małym zdawać nie może”, Golański 1801: 171). Wyimki te tłumaczone są prozą i, podobnie jak w przypadku Mihanowicza, autor podzielił je na akty i sceny. Nie dziwi to, jeśli uświadomimy sobie, że Golański był także autorem cenionego podręcznika poetyki klasycystycznej O wymowie i poezji z 1808 roku. Biorąc pod uwagę, że zwracał on uwagę na wartości etyczne literatury (był też tłumaczem Plutarcha), należy doszukiwać się klucza w takim wyborze tekstów. I rzeczywiście owe wyimki są opatrzone komentarzem do zachowań bohaterów.

$\mathrm{Na}$ stanowisku wykładowcy na katedrze wymowy Uniwersytetu Wileńskiego Golańskiego zastąpił Euzebiusz Słowacki (1773-1814), teoretyk i historyk literatury, tłumacz, o którym na koniec także warto wspomnieć. Pikanterii tej historii dodaje fakt, że jego kandydaturze sprzeciwiał się sam Groddeck, który skrytykował zarówno pracę Słowackiego przedłożoną w roku 1811 jako aplikację na stanowisko profesora, jak i jego przekład Elektry Sofoklesa zamieszczony w tejże pracy. W pośmiertnym wydaniu Euzebiusza Słowackiego Dzieł z pozostałych rękopisów ogłoszonych, w tomie trzecim zawierającym rozbiory pisarzów i przykłady stylu w prozie (1826) znajdujemy dwa ustępy z Sofoklesa: Elektry trzymającej w ręku urnę, w której mniema, iż mieszczą się popioły Orestesa (epeisodion czwarte) oraz epeisodion z Ajasa, monolog przed popełnieniem samobójstwa przez tytułowego bohatera - oba w przekładzie prozatorskim.

Zdaniem Słowackiego praca tłumacza nie polega bowiem na powierzchownym oddaniu kształtu dzieł czy na dosłowności, ale na roztropnie użytej wolności (nie swawoli bez granic), na wierności użytej z rozsądkiem i smakiem przy jednoczesnym zastrzeżeniu, że tłumacz powinien stosować się do praw języka, na który przekłada, do praw dobrego smaku i przystojności (Słowacki 1826: 448-465). Podobnego zdania był także wspomniany już książę Czartoryski (Węclewski 1876: 82), według którego ocena przekładu należy do profesora literatury polskiej. Zapewne to ta właśnie kwestia nie spodobała się Groddeckowi, który uważał, że tłumacz nie może modernizować, tłumacząc dzieło starożytnego autora; że nie wolno mu zniekształcać piękności oryginału; że nie wolno mu „przystrajać oryginału w nowoczesne gałgany, aby tylko zadowolić 
niewybredny smak współczesnych" (Oko 24-25). Słowacki, podobnie jak Wężyk, był klasycystą uwzględniającym nowe tendencje w literaturze.

Zdaniem Tomasza Swobody przekład jest integralną częścią dyskursu swoich czasów i jako taki odzwierciedla intelektualne postawy, a zarazem pomaga je kształtować (Swoboda 159-160). Oczywiście omawianym przekładom trzeba by się przyjrzeć znacznie bliżej szczególnie w odniesieniu do indywidualnych wyborów translatorskich w nich zastosowanych. Niemniej to sprzężenie między pojawieniem się polskich przekładów a trwającym akurat sporem estetycznym oraz narzekaniami na brak bądź uwiąd polskiej tragedii (por. Dmochowski 80; Golański 1808: 546; Korzeniowski 268, 270; Słowacki 1833: 306; Czwórnóg-Jadczak 44) wydaje się frapujące i nieprzypadkowe. I osobiście chciałabym sądzić, że kryje się za tym coś więcej niż ówczesna moda na francuską kulturę. Na uwikłanie przekładów w ów spór wskazywać mogą z pewnością słowa Chmielowskiego ${ }^{7}$, który za konsekwencję owego rozdźwięku estetycznego uznał przerwę w ukazywaniu się przekładów starożytnych tekstów pomiędzy 1830 a 1850 rokiem (por. Wężyk 1878: 339-340). I rzeczywiście wzmianki w literaturze przedmiotu, do których udało mi się dotrzeć, potwierdzają tę lukę w odniesieniu do przekładów tragików (oczywiście należałoby spojrzeć także i na innych autorów), przy czym sprawa ta z pewnością jest znacznie bardziej złożona, ponieważ jakkolwiek „duch powiał w stronę romantyzmu”, to niewątpliwie polscy romantycy pełnymi garściami czerpali z tradycji antycznej, w tym też z formy tragedii greckiej. Po 1850 roku, o czym wspomniałam na początku, przekłady te jawią się nam już znacznie wyraźniej (cezura ta jest jednak na tyle wyraźna, że przyjęłam ją w niniejszym artykule). Niemniej, jak starałam się pokazać, te niekiedy niepewne, niekiedy fragmentaryczne, wzbudzające niejednokrotnie wątpliwości czy zmuszające do stawiania kolejnych pytań, wymagające z pewnością dalszych poszukiwań i badań początki wzbudziły pewien ferment, który torował drogę przyszłym tłumaczom. Ci natomiast wzbogacali tak kulturę, jak i język polski, by w zakończeniu przytoczyć piękne słowa Euzebiusza Słowackiego:

język polski jest jednym z wielu teraźniejszych języków najzdatniejszym do dobrego dzieł obcych przekładu. Jego natura i układ, tyle do języ-

7 Tak o tym pisze: „Zaledwie się umysły oswoiły z treścią i formą starożytnej tragedii $\mathrm{w}$ jej najlepszym przedstawieniu, gdy duch powiał w inną stronę. Zwyciężył romantyzm. Nastąpiło zobojętnienie dla literatury greckiej przez złość do konwencjonalności francuskiej. Co tylko przypominało klasycyzm, poszło w poniewierkę" (Chmielowski 661). 
ków starożytnych podobieństwa mający; jego bogactwo, ofiarowujące piszącemu tyle wyrazów do malowania wszystkich kształtów myśli, i najmniejszych cieniów między wyobrażeniami śrzodkujących; jego składnia, niepoddana bynajmniej prawom niewolniczego wyrazów szyku, mnóstwo słów nie tylko dla rozumu ale i ucha malujących, łatwość do wyrażeń równie zwięzłych jak dokładnych i jasnych, wolność składania i przecinania okresów, co do liczby krasomówskiej nieustępujących łacińskim; wszystko to pod piórem biegłego mistrza czyni ten język bardzo dzielnym rozumu i imaginacyi narzędziem. Do nas tylko należy pracować nad jego doskonaleniem, i czy to w pismach własnych, czy w tłumaczeniu obcych, starając się usilnie o gładkość i poprawność mowy, trwać w tym przekonaniu, że nas nic upoważnić nie może do gwałcenia praw, jej naturą i powagą zwyczaju uświęconych (Słowacki 1826: 464-465).

\section{| Bibliografia}

Aischylos. Prometeusz skowany. Przeł. Jan Kasprowicz. Kraków: Krakowska Spółka Wydawnicza, 1925.

Chmielowski, Piotr. „Tragedye Sofoklesa. Przekład Z. Węclewskiego”. Ateneum 3 (1876). S. 659-679.

Cywiński, Stanisław. Literatura $w$ Wilnie i Wilno w literaturze. Wilno: Druk „Lux”, 1934.

Czwórnóg-Jadczak, Barbara. Klasyk aż do śmierci. Twórczość literacka Franciszka Wężyka. Lublin: Wydawnictwo umcs, 1994.

Dmochowski, Franciszek, Ksawery. Sztuka rymotwórcza. Wrocław: Zakład im. Ossolińskich, 1956.

Eliaszewicz, Tadeusz. „Ogólne uwagi nad klasycznością i romantycznością”.

Dziennik Wileński. Historya i Literatura. T. 5, 1 (1828). S.43-57. T. 5, 2 (1828).

S.73-87. T.5, 3 (1828). S. 169-195.

Eliaszewicz, Tadeusz. „Wiek Sofoklesa, w którym pisał Tragedyą, Edip w Kolonie”. Dziennik Wileński (1829). S. 31-49, 96-126.

Eliaszewicz, Tadeusz. Edyp w Kolonie. Wilno: nakład i druk A. Marcinkowskiego, 1829.

Estreicher, Karol. Bibliografia polska XIX stólecia. T. 5 (W-Z). Kraków: czcionkami drukarni C.K. Uniwersytetu Jagiellońskiego, $188 \mathrm{o}$.

Garnier, Bruno. „La traduction de la tragédie grecque en France: le tournant décisif de la période". Traduction, terminologie, rédaction 11, 1 (1998). S. 33-64. 
Golański, Filip Neryusz. Allegorye starożytne w stosunku do I wieku Sławnych ludzi Plutarcha i czasów bohatyrsko-mitologicznych. Wilno: w Drukarni Akademickiej, 1801.

Golański, Filip Neryusz. O wymowie i poezyi. Wilno: nakładem Józefa Zawadzkiego, 1808.

Groddeck, Gotfryd Ernest. Trachiniae graece. Wilno: typis et impensis Iosephi Zawadzki Academiae Typographi, 1808.

Grzebień, Ludwik. Jan Mihanowicz. Web. 15.05.2019. <https://tinyurl.com/ ycm8n4p2>

Kaszewski, Kazimierz. „Trachinki, tragedya Sofoklesa”. Biblioteka Warszawska 2 (1865). S. 1-50.

Korzeniowski, Józef. Kurs Poezyi. Warszawa: nakładem i drukiem N. Glücksberga, 1829.

Kraskowska Ewa, Kwiatkowska Agnieszka, Grądziel-Wójcik Joanna. „Ars poetyka”. Forum Poetyki (2015). S. 76-84. Web. 02.08.2019. <https://tinyurl.com/ y98zab35>

Lewestam, Franciszek Henryk. Historya Literatury Powszechnej. T. 1. Warszawa: nakładem Aleksandra Lewińskiego Księgarza, 1863.

Łanowski, Jerzy. „Wstęp do Orestesa”. Eurypides. Tragedie. T. 3. Warszawa: Prószyński i S-ka, 2007. S. 182-185.

Mihanowicz, Jan. Orestes. Wilno: druk M. Romma i Z. Szrift-Gissera, 1829.

Nekrologi (Alfons Walicki). Przegląd Poznański 26 (1858). S. 375.

„O dramatyce u dawnych”. Nowy Pamiętnik Warszawski (1801). S. 216-226.

Oko, Jan. Seminarjum filologiczne Godfryda Ernesta Grodka. Wilno: nakładem Towarzystwa Przyjaciół Nauk, 1933.

Parandowski, Jan. „Homeryckie boje”. O sztuce tłumaczenia. Red. M. Rusinek. Wrocław: Zakład im. Ossolińskich, 1955. S. 299-311.

Piechota, Marek. Słowo to cały człowiek. Studia i szkice o twórczości Mickiewicza. Katowice: Wydawnictwo Uniwersytetu Śląskiego, 2011.

Prometeusz w okowach. Tragedya po Grecku przez Aeschylos[a]. Po polsku przez J[ózefa] G[abriela Alojzego] Biernackiego. 1815. Rękopis sygn. 271 w zbiorach Poznańskiego Towarzystwa Przyjaciół Nauk. Web. 02.08.2019. <https://tinyurl.com/yb2994aj>

Przewodnik (nekrolog Alfonsa Walickigo). Dziennik Literacki 1 (1859). S. 12.

Skwara, Ewa. Komedia według Terencjusza. Warszawa-Toruń: Fundacja na rzecz Nauki Polskiej, 2016.

Słowacki, Euzebiusz. Dzieła z pozostałych rękopisów ogłoszone. Wilno: Józef Zawadzki własnym nakładem, 1826.

Słowacki, Euzebiusz. Prawidła wymowy i poezyi wyjęte z dzieł Euzebiusza Słowackiego: dziełko szkołom w Królestwie Polskiem przepisane. Warszawa: nakładem Zawadzkiego i Węckiego, 1833. 
Sobolewski, Ludwik. „Chór z Trachinek, tragedii Sofoklesa (w. 94-141)”. Tygodnik Wileński 1816. S. 159.

Sowiński, Leonard. Rys dziejów literatury polskiej podtug notat Aleksandra Zdanowicza oraz innych źródeł. T. 4. Wilno: nakładem i drukiem Józefa Zawadzkiego, 1877.

Srebrny, Stefan. „Georges Méautis, Eschyle et la trilogie. Paris, Grasset 1936. Str. 284; Franz Stoessl, Die Trilogie des Aischylos. Formgesetze und Wege der Rekonstruktion. Raden bei Wien, Rohrer 1937. Str. 264". Scena Polska 14 (1937). S. 367-371.

Staszewski, Janusz. Generał Józef Biernacki. Poznań: Towarzystwo Miłośników Historji w Poznaniu, 1936.

Swoboda, Tomasz. Powtórzenie i różnica. Szkice z krytyki przekładu. Gdańsk: Wydawnictwo w podwórku, 2014.

Tomkowicz, Stanisław. „Przyczynek do historyi początków romantyzmu w Polsce”. Archiwum do dziejów literatury i oświaty w Polsce. T. 1. Kraków: nakładem Akademii Umiejętności, 1878. S. 265-340.

Walicki, Alfons (przeł.). Król Edyp. Arcydzieła dramatyczne w przekładach Józefa Korzeniowskiego i Alfonsa Walickiego. T. 2. Wilno: nakład i druk Józefa Zawadzkiego, 1845.

Węclewski, Zygmunt. „Studya w Polsce nad literaturą grecką w czterech przeszłych wiekach i przekłady tragików na język polski”. Biblioteka Warszawska 4 (1861). S. 178-19o.

Węclewski, Zygmunt. „Wiadomości o życiu i pismach G.E. Groddka”. Rozprawy i sprawozdania z posiedzeń Wydziału Filologicznego Akademii Umiejętności 4 (1876). S. 1-157.

Wężyk, Franciszek. Barbara Radziwiłtówna. Tragedia w 5 aktach oryginalnie wierszem napisana. O poezji dramatycznej. Kraków: księgarnia A. Grabowskiego, 1822.

Wężyk, Franciszek. Bolesław Śmiały. Tragedia w 5 aktach. O poezji dramatycznej. Kraków: księgarnia A. Grabowskiego, 1822.

Wężyk, Franciszek. Gliński. Tragedia w 5 aktach wierszem. O poezji dramatycznej. Kraków: w komissie u A. Grabowskiego, 1821.

Wężyk, Franciszek. Poezye. Z pośmiertnych rękopisów. Tom I: tłumaczenia klasyków. Kraków: nakładem rodziny autora, 1878.

Wiadomości Literackie. Biblioteka Warszawska 2 (1864). S.149.

Wołoszyński, Ryszard. Polacy w Rosji: 1801-1830. Warszawa: Książka i Wiedza, 1984. Zawiliński, Roman. „O polskich przekładach tragedyi Sofoklesowych”. Biblioteka Warszawska 3 (1881). S. 365-381.

Zdanowicz, Aleksander. Rys dziejów literatury polskiej. T. 4. Wilno: Józef Zawadzki, 1874.

Żołkowski, Aleksander. „Wstęp”. Tygodnik Wileński 1816. S. 1-2. 


\section{| Abstrakt}

\section{BARbARA Bibik}

\section{Zapomniani tłumacze starożytnych greckich tragedii}

Z licznego, jak się okazuje, korpusu polskich przekładów greckich tragedii powszechnie funkcjonuje zaledwie kilka nazwisk tłumaczy. Na rozpoznanie wciąż czekają kolejni tak dziewiętnasto-, jak i dwudziestowieczni tłumacze. Jako przyczynek do zarysu historii polskiej literatury tłumaczonej chciałabym w niniejszym artykule skoncentrować się przede wszystkim na tych mniej znanych, dziewiętnastowiecznych tłumaczach starożytnej literatury dramatycznej. Są oni dzisiaj często zapomniani, a przecież torowali drogę starożytnym dramatom w polskiej kulturze w nie mniejszym stopniu niż te zapamiętane, wielkie nazwiska. Dodatkowo chciałabym się przyjrzeć proponowanym przez nich ówczesnej publiczności tekstom, nie zawsze stanowiącym oczywisty wybór spośród zachowanego korpusu starożytnych tragedii.

Słowa kluczowe: tragedia grecka, filologia klasyczna, klasycyzm, przekład, poetyka

\section{| Abstract}

BARBARA BIBIK

\section{The Forgotten Translators of Ancient Greek Tragedies}

There is an ample number of Polish renditions of ancient Greek tragedies. Unfortunately, only a few names of those Polish translators are commonly known. The rest, written especially in the 19th century, is still waiting for someone to be interested in their works. Therefore, in my paper I would like to focus on the unrecognized translators from this century. They are widely forgotten today, yet they did great work at the time to acquaint the Polish public with Greek tragedies. My aim is also to recognize the tragedies they chose to translate which often seem not to be an obvious choice.

Keywords: Greek tragedy, classical philology, classicism, translation, poetics 


\section{| Nota o autorze}

Barbara Bibik - profesor w Katedrze Filologii Klasycznej UMK w Toruniu. Podstawą nadania stopnia doktora habilitowanego była monografia „Translatoris vestigia. Projekcje inscenizacyjne wybranych polskich tłumaczy Orestei Ajschylosa” (2016). Stypendystka Fundacji Lanckorońskich, Fundacji z Brzezia Lanckorońskich. Od 2007 roku prezes Zarządu Fundacji Traditio Europae. Współpracuje z Krajowym Funduszem na rzecz Dzieci. Zajmuje się tragedią grecką i jej recepcją oraz problematyką przekładów z języków klasycznych; interesuje się także dziedzictwem grecko-rzymskiego antyku oraz rolą i miejscem kobiety w społeczeństwie starożytnym.

E-mail: bb@umk.pl 